\title{
К ВОПРОСУ О ВОЗВРАТЕ ПОШЛИН И АКЦИЗА ПРИ ВЫВОЗЕ ТОВАРА ЗА ГРАНИЦУ НА ДАЛЬНЕВОСТОЧНОЙ ТАМОЖЕННОЙ ГРАНИЦЕ РОССИИ В НАЧАЛЕ ХХ ВЕКА
}

В статье анализируются вопрос о сложении акциза, возврате пошлин при экспорте российских товаров за рубеж и реэкспорте китайских товаров из России. Как правило, возвратом части стоимости товара - акциза, в случае экспорта российских товаров в Китай занимались крупные российские компании. Просили о возврате ранее уплаченных таможенных пошлин, в случае если китайский товар не нашел сбыта в России представители российских магазинов и китайские мелкие или средние предприниматели, реэкспортирующие китайскую продукцию. Особый повод для работы сотрудникам российской таможни, создавали китайские товары, ввозимые в Россию для личных нужд. До 1913 г. китайские товары ввозились в российскую 50 верстную приграничную зону беспошлинно. Однако таможенники выявляли среди товаров будто бы китайского происхождения товары иных иностран- 
ных держав. Кроме того, задерживался и облагался пошлиной китайский товар, если было очевидно, что при его создании использовалось сырье других государств, которые не имели с Россией договоров о беспошлинной торговле.

Ключевые слова: Таможня, Сунгарийская брандвахта, сбыт, акциз, пошлина, Департамент таможенных сборов, таможенные пломбы, льготная полоса.

V.V. SINICHENKO

\section{ON THE ISSUE OF THE RETURN OF DUTIES AND EXCISE IN THE EXPORT OF GOODS ABROAD ON THE FAR EASTERN CUSTOMS BORDER OF RUSSIA IN THE EARLY TWENTIETH CENTURY}

The article analyzes the issue of the addition of excise duty, the return of duties on the export of Russian goods abroad and the re-export of Chinese goods from Russia. As a rule, the return of part of the value of the goods excise, in the case of exports of Russian goods to China were engaged in large Russian companies. Asked for the return of previously paid customs duties, if the Chinese goods are not sold in Russia, representatives of Russian stores and Chinese small or medium-sized businesses that re-export Chinese products. Chinese goods imported to Russia for personal needs created a special reason for the work of the Russian customs officers. Until 1913, Chinese goods were imported into the Russian 50 verst border zone duty-free. However, customs officers identified goods of other foreign powers as if of Chinese origin. In addition, Chinese goods were delayed and taxed if it was obvious that the raw materials of other States that did not have duty-free trade agreements with Russia were used in its creation.

Keywords: Customs, Sungarii defense service, sales, excise, duty, Department of customs duties, customs seals, preferential strip.

В начале $X X$ в. после устройства таможенных учреждений по морской (1909 г.) и сухопутной (1913 г.) границе России на Дальнем Востоке возник вопрос о сложении акциза, возврате пошлин и других сборов (транспортных) за экспорт российских товаров за рубеж. Этот вопрос уже был затронут в общих чертах в отечественной историографии [1].

Мы же попытаемся на страницах этой работы детализировать механизм возврата и компенсации министерством финансов Российской империи тех затрат, которые несли предприниматели при перемещении товара через таможенную линию в изучаемом регионе.

Так, Благовещенская таможня получила 12 апреля 1912 г. заявление от «Восточно-Азиатского нефтяного промышленного товарищества» о возврате акциза, внесенного ранее на депозит Приамурского акцизно- 
го управления за вывезенный за границу в Маньчжурию керосин в количестве 400 ящиков, весом нетто 720 пудов. Товарищество в качестве доказательства предоставило свидетельство о вывозе товара [2, л. 19].

Кроме того, товар не подлежал таможенному обложению и за него возвращались ранее уплаченные таможенные платежи, в случае если он ранее был ввезен в Россию, но не нашел здесь сбыт и вывозился обратно на родину.

Как свидетельствует дело 158 Российского государственного исторического архива Дальнего Востока (фонд 1303) «Об обратном отвозе в Маньчжурию товаров» за период с 24 мая 1912 г. по 6 марта 1913 г. министерством финансов таким образом было возвращена сумма в 86743 p.

Департамент таможенных сборов Министерства фринансов России в письме от 31 августа 1912 г. Хабаровской таможне описывал процедуру возврата «Вследствие представления от 13 августа с.г. за № 3245, Департамент Таможенных сборов дает знать таможне для исполнения и объявления Ван Докуну, что на основании ст. 596 и 598 Уст. Таможенного, Департамент признал возможным удовлетворить ходатайство просителя о разрешении вывезти обратно в Маньчжурию 2 места полотенец, доставленных по накладной за № 319, при условии представления командиром парохода, на коем будет отправляться товар, обязательство предъявить груз Сунгарийской брандвахте с целыми пломбами на местах» [3, д. 158, л. 49].

Департаментом таможенных сборов было разрешено некоторым торговым фирмам в Хабаровске, в виду их ходатайств, вывезти обратно за границу в Харбин товары под залоги в размере суммы пошлины, с непременным условием предъявления таких товаров Харбинской полиции для удостоверения о действительности их прибытия в Харбин.

В виду изложенного Хабаровская таможня уведомила 10 ноября 1912 г. Харбинское городское полицейское управление, что таможней на каждый отдельный транспорт выдалось провозное свидетельство с подробным указанием в нем рода и количества товара, при чем каждое место было опломбировано двумя пломбами Хабаровской таможни, и товары эти вместе с провозными свидетельствами должны были предъявляться Харбинской полиции, которая убедившись, что число мест, знаки, номера, род товара и вес брутто сходны с показанными в свидетельстве, должно делать об этом отметку на привозном свидетельстве и вместе со снятыми пломбами возвращать вышеназванные документы таможне [3, д. 158, л. 79].

Еще порождал процедура возврата и компенсации и такой юридический факт - до 1913 г. таможенному обложению пошлиной не подлежал китайский товар, ввезенный по сухопутной границе в Россию в пределах 50 верстную приграничной зоны. 
Так, начальник Приамурского таможенного округа 5 сентября 1909 г. сообщал руководству Хабаровской таможенной заставы: «По дошедшим до меня сведениям, из Хабаровска по железной дороге отправляется за пределы 50-верстной полосы (с российской стороны от границы) в значительном количестве чумизная крупа китайского происхождения, причем для беспрепятственного провоза сей крупы транспорты ею покрываются полицейскими удостоверениями о местном происхождении, предъявляемыми таможенными чинами. Давая об этом знать, предлагаю Заставе иметь самый строгий контроль за передвижением означенной крупы за пределы льготной полосы, и предъявляемые полицейские удостоверения о местном происхождении ее подвергать, в случаях сомнения, проверке негласным путем о действительном происхождении товара» [3, д. 100, л. 35].

Таким образом, до 1913 г. китайский товар ввозился по сухопутной границе беспошлинно. Вместе с тем за подобную операцию взыскивались с владельца определенные сборы за оформление накладной на груз.

Так в свидетельстве о происхождении товара № 741 от 5 мая 1912 г. выданном в г. Шанхай, говорилась: «Свидетельство дано Императорским российским генеральным консульством в Шанхае фирме «Тун Шун Ки» в удостоверение того, что отправленный на пароходе «Кобе Мару» в Благовещенск, Иман и Хабаровск на имя Сон Хошина товар в количестве 20 мест (10 мест китайской бумажной полосатой ткани на 50 кусков; 10 мест китайской бумажной белой суровой ткани на 20 кусков - представляют товар китайского происхождения, что и удостоверяется сим приложением казенной печати. По ст. 26 Тарифа Устава консульского взыскано 4 р. 50 к. или мексиканских долларов - 5,85. За генерального консула Г. Ящинский [3, д. 158, л. 70]».

Перед самым закрытием беспошлинного ввоза китайских товаров на Дальний Восток России возникли определенные правонарушения.

Так, в декабре 1912 г. департамент таможенных сборов, отмечал, что 15 мая 1912 г. в Хабаровск на пароходе «Хлопец» по накладной № 19 в адрес китайского подданного Поу Сунтуня из Харбина прибыло 3 места туфель китайских и 11 мест одежды китайской, всего 14 мест общим весом в 114 пудов 20 фунтов, и 28 мая 1912 г. на пароходе «Великий князь Алексей» по накладной № 78 прибыло 5 мест одежды китайской, общим весом 37 пудов 20 фунтов. По осмотре этого товара чинами Хабаровской таможенной заставы как в первой партии 14 мест, так и во второй 5 мест, часть товаров оказалась с иностранными клеймами и поэтому товар этот - как сомнительного происхождения был заставой принят в пакгауз для оплаты пошлиной или для обратного вывоза за границу.

Представленные Поу Сунтунем консульские свидетельства за № 5149 и 5429 о китайском происхождении ввезенного в Россию товара, 
как выданные лишь на основании приложенных к ним удостоверений Китайского коммерческого общества в Харбине, не были признаны заставой подлинными и законными.

Тем не менее, Поу Сунтунь оспорил решение «О не выпуске 14 мест» и пожаловался в письме на имя министра финансов России. Вследствие этого 20 июня 1912 г. телеграммою Департамента таможенных сборов от Хабаровской заставы было затребовано объяснение, а затем телеграммою от 12 сентября 1912 г. и предписанием от 19 сентября 1912 г. за № 32473 уже Хабаровской таможне было предложено ту часть товара из числа 14 мест, в китайском происхождении которой не возникало сомнения, выдать владельцу. Это решение таможней 19 сентября 1912 г. было исполнено.

Весь товар тогда в 14 местах был рассортирован и 7 мест с китайским платьем выпущен был тогда беспошлинно, а остальные 7 мест с платьем, имевшим на себе иностранные клейма (американские и британские) было предложено Поу Сунтуню или получить с оплатой пошлины или вывезти обратно за границу.

С означенным решением таможни Поу Сунтунь согласился и письменно на постановление Таможни заявил, что 7 мест желает вывезти обратно в Харбин. Поу Сунтунь не желал внести пошлину, исчисленную русской таможней в 7479 р. 89 к.

Поэтому Поу Сунтунь подал прошение о разрешении вывезти часть ранее ввезенного товара обратно в Харбин. С получением же предписания Департамента таможенных сборов от 8 октября за № 34646 о разрешении ему вывезти в Харбин 7 мест, под залог пошлины, китаец всячески оттягивал вывоз товара и просил Таможню разрешить оставить товар на хранение в таможне до открытия навигации. Так как согласно ст. 477 Таможенного устава срок складки товара на хранение для Таможни 2 класса, был установлен в 2 месяца, ему было отказано. 8 ноября 1912 г., Таможней было объявлено Поу Сунтуню, что по исчислении со дня последнего решения Департамента двухмесячного срока хранения его товара, в случае его не вывоза в Харбин, он будет назначен Таможней в продажу.

В качестве компромисса таможня предложила товары из 1 партии в 7 мест (из числа 14) досмотренных по очистке в книге досмотра за № 37 и № 15 и товаров из 2-й партии в 5 мест, досмотренных по очистке в книге за № 18 и № 16 выслать в Китай посылкой по почте. Однако это не устроило китайца, так как почтовая пересылка оплачивалась бы им.

Так как Поу Сунтунь залога за хранение товара внести не смог он возбудил перед Департаментом новый вопрос о второй партии в 5 мест, о которых с 28 мая 1912 г. ранее ничего не упоминал. Вопрос этот возбужден, по мнению сотрудников Хабаровской таможни, исключительно из желания протянуть время и затем ходатайствовать о разрешении об- 
ратного вывоза товара по Амуру пароходом без залога и пошлин, как это разрешалось Департаментом таможенных сборов во время работы навигации, т.е. с конца апреля каждого года.

Своего китаец добился. Так Департамент в письме от 24 января 1913 г. в Хабаровскую таможню сообщил, что товарищ министра фиинансов по докладу Департамента, признал возможным удовлетворить ходатайство китайского подданного Поу Сунтуня об обратном вывозе товара в Харбин, в навигацию 1913 г. 12 мест мануфактурных товаров, означенных в представлении таможни от 24 декабря 1912 г.». Переправить означенный груз должна была Сунгарийская брандвахта порядком, изложенным в предписании Департамента от 16 июня 1912 г. за № 20915 [3, д. 158, л. 125].

Таким образом, таможня, задержала 12 мест с мануфактурой главным образом из-за того, что в числе товаров имелись части с иностранными клеймами. Поэтому у сотрудников таможни, при отсутствии к тому же определенного удостоверения русского Консула в китайском происхождении товара, возникло сомнение в законности беспошлинного ввоза подобного товара.

Цветная китайская одежда, не имеющая на себе иностранных клейм, таможней пропускалась беспошлинно. Вместе с тем таможня внимательно досматривала мануфактуру, ввозимую по китайским консульским свидетельствам, и в случае, если одежда даже была оформлена как китайского производства, но с иностранными клеймами на ткани, сотрудники составляли специальный акт и требовали уплатить установленные таможенные сборы и пошлины [3, д. 158, л. 121].

Итак, накануне Первой мировой войны на дальневосточной таможенной границе России был актуален вопрос о возврате акциза за товары вывозимый для реализации в Китай. Кроме того, Департамент таможенных сборов часто решал вопросы о возврате ранее уплаченных таможенных платежей, в случае если товар ранее был ввезен в Россию, но не нашел здесь сбыт и вывозился обратно на родину.

Достаточно спорным для сотрудников таможни до 1913 г. был вопрос об освобождении от таможенного обложения ввозимого в Россию товара китайского происхождения. Таможенники выявляли в китайском товаре, перемещенным по сухопутной границе в Россию в пределах 50-верстной приграничной зоны, товары иностранного происхождения. Кроме того, задерживался китайский товар, если было очевидно, что при его создании использовалось сырье других государств, которые не имели с Россией договоров о беспошлинной торговле.

\section{Список использованной литературы и источников}

1. Беляева Н. А. От Порто-Франко к таможне: очерк региональной истории российского протекционизма / Н. А. Беляева. - Владивосток : Дальнаука ВФ PTA, 2003. - 212 c. 
2. Российский государственный исторический архив Дальнего Востока (далее РГИА ДВ). - Ф.1306. - Оп. 1. - Д. 95.

3. РГИА ДВ. - Ф. 1303. - Оп. 1.

\section{Информация об авторе}

Синиченко Владимир Викторович - доктор исторических наук, професcop, начальник кафедры гражданско-правовых дисциплин, Восточно-Сибирский институт МВД России, 664071, г. Иркутск, ул. Лермонтова, 110; e-mail: v.v.sinichenko@bk.ru

\section{Author}

Vladimir V. Sinichenko - Doctor of History, Professor, Chief of Department Civil Law Disciplines, East Siberian Institute Ministry of Internal Affairs of the Russian Federation, 110 Lermontov St., 664071, Irkutsk, Russia; e-mail: v.v.sinichenko@bk.ru 